\title{
GMPS wt Allele
}

National Cancer Institute

\section{Source}

National Cancer Institute. GMPS wt Allele. NCI Thesaurus. Code C97523.

Human GMPS wild-type allele is located in the vicinity of 3q24 and is approximately $70 \mathrm{~kb}$ in length. This allele, which encodes GMP synthase [glutamine-hydrolyzing], is involved in the modulation of purine synthesis. A chromosomal translocation $\mathrm{t}(3,11)(\mathrm{q} 25, \mathrm{q} 23)$ of this gene and the MLL gene is associated with treatment-related acute myeloid leukemia. 